\title{
Primary aortic thrombus in young: a rare site, a novel treatment
}

\author{
T R Raghu, ${ }^{1}$ Navin Agrawal, ${ }^{1}$ Madhav Hegde, ${ }^{2}$ C N M Anjunath ${ }^{1}$
}

${ }^{1}$ Department of Cardiology, Sri Jayadeva Institute of Cardiology, Bengaluru, Karnataka, India

${ }^{2}$ Department of Radiology, Sri Jayadeva Institute of Cardiology, Bengaluru, Karnataka, India

\section{Correspondence to} Dr Navin Agrawal, drnavinagrawal@gmail.com
To cite: Raghu TR, Agrawal N, Hegde $\mathrm{M}$, et al. BMJ Case Rep Published online: [please include Day Month Year] doi:10.1136/ bcr-2013-010304

\section{DESCRIPTION}

A 35-year-old man previously asymptomatic, nonsmoker presented with a history of acute onset severe ischaemic pain, paraesthesia and pulselessness involving the left upper limb from the axillary artery distally since 3 days, not preceded by fever or chest pain. ECG was normal and transthoracic echocardiogram showed a normally functioning heart with an abnormal mass in the arch of aorta, which could not be characterised adequately. There was no aortic regurgitation.

CT aortogram revealed a large, immobile thrombus fixed in the arch of aorta causing subtotal occlusion of the ostium of the left subclavian artery, with the rest of the aorta having no evidence of atherosclerosis or aortitis and the coronaries were normal (figures 1-3).

The subsequent workup including analysis for dyslipidaemia, protein $\mathrm{C}$ and protein $\mathrm{S}$ and antiphospholipid antibody, erythrocyte sedimentation rate, $\mathrm{C}$ reactive protein, rheumatoid factor and antinuclear antibodies did not reveal any obvious predisposing factor. There was no historical or investigational evidence suggestive of any malignancy, connective tissue disorder or claudication or any family history of predisposition.

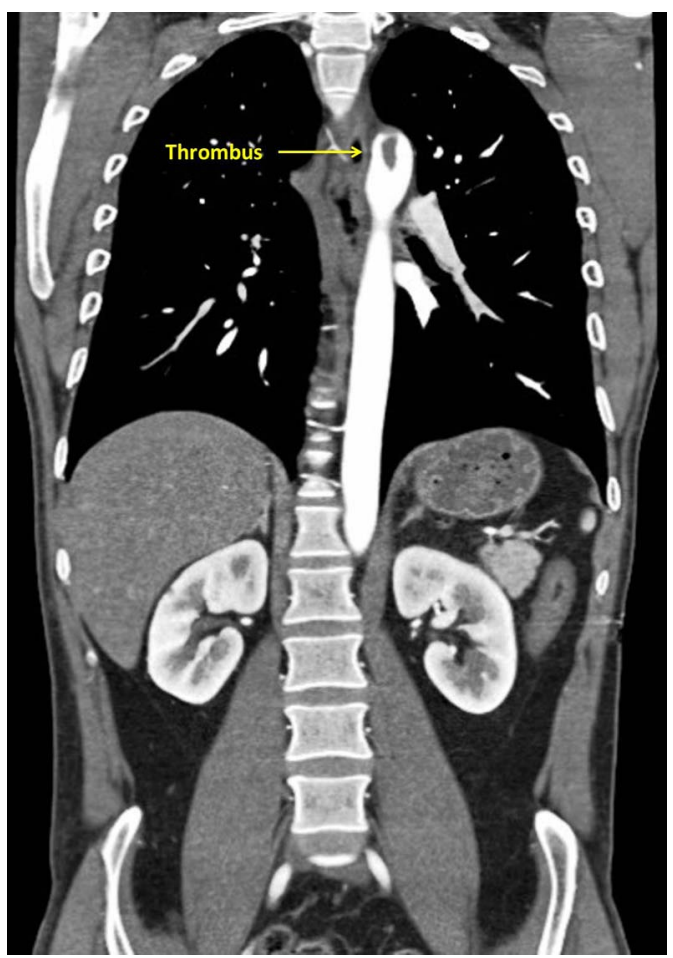

Figure 1 Coronal view of a large thrombus attached to the descending aorta at the origin of the subclavian artery.

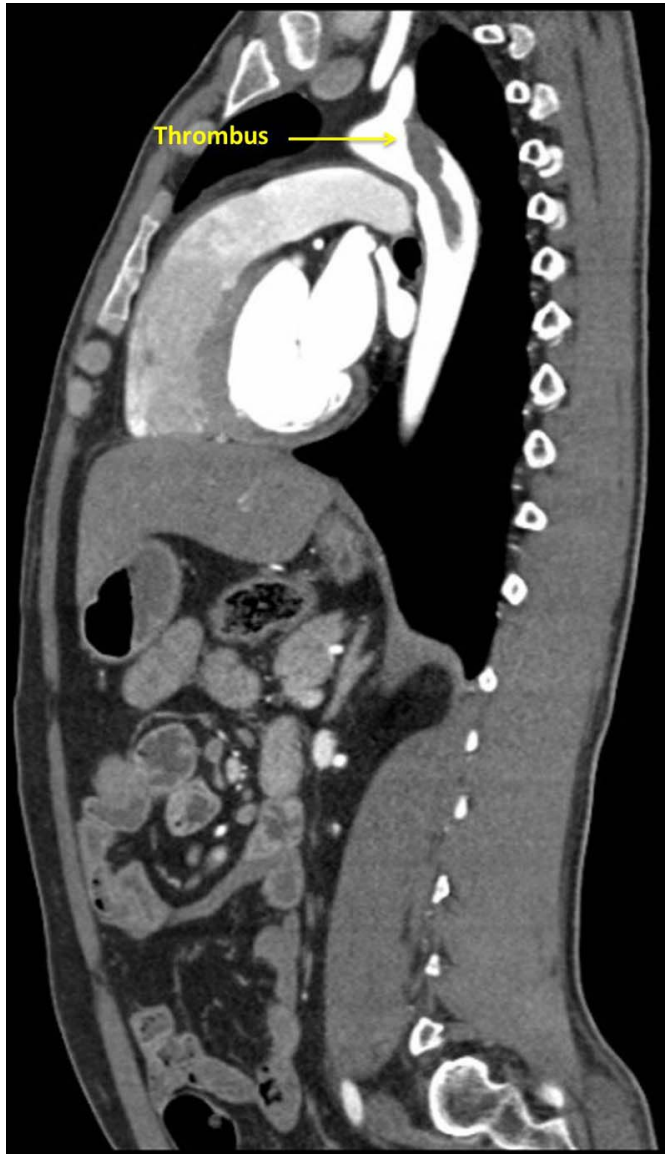

Figure 2 Sagittal view of a large thrombus attached to the descending aorta at the origin of the subclavian artery.

The site of thrombus was not amenable for surgical extraction without significant risks. The patient was subsequently thrombolysed with an infusion of streptokinase because of limb-threatening severe ischaemic pain and pulselessness. Heparin and anticoagulants have been shown to prevent thrombus propagation but its efficacy in dissolution of previously formed thrombus is uncertain. The patient had transient left hemiparesis persisting for 3-4 h during lysis, which was stopped immediately. The reason of selective embolisation to the right carotid from a relatively distant site could not be explained.

There was subsidence of all ischaemic symptoms in the limb and the echocardiogram showed no mass in the aorta and CT of the brain was normal. The patient was discharged on the fourth day on oral anticoagulation which was planned to be continued for at least 6 months. Statins and angiotensin-converting enzyme inhibitors were not 


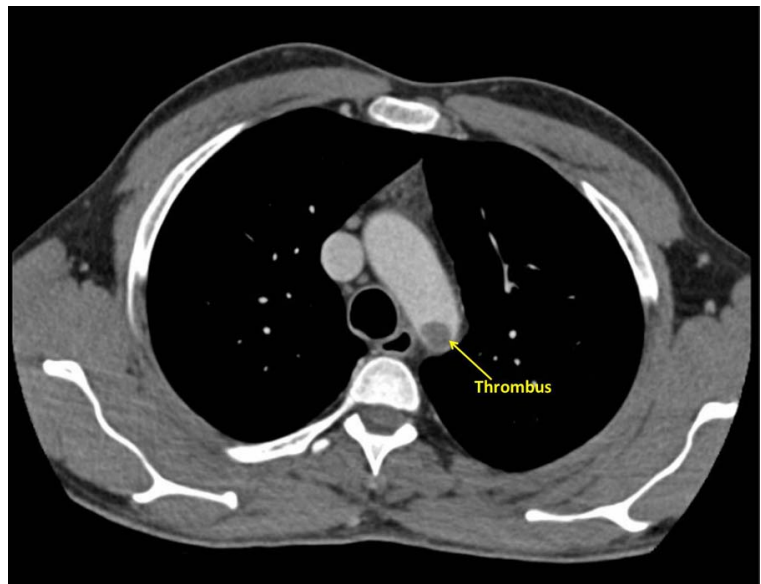

Figure 3 Short axis view of the arch of aorta showing the presence of a large thrombus.

considered as there was no evidence of atherosclerosis and coronary involvement.

Subsequent follow-up since the last 5-6 months has been uneventful. CT aortogram was not been performed during follow-up as the patient was asymptomatic and unwilling.

This unique combination of presence of an aortic thrombus at an unusual site which is subjected to high blood flow and turbulence without any predisposing factor, responsive to thrombolysis has not been reported previously in the literature. ${ }^{1-3}$

\section{Learning points}

- Descending aorta can be a rare site of idiopathic thrombus, which can rarely be fixed. CT and blood workup can help in aetiology assessment.

- Thrombolysis could provide a successful non-surgical modality of treating thrombus in the aorta, which is not amenable to surgical access in patients having no other contraindications for lysis.

- Risk of stroke and peripheral embolism should be taken into account, especially in thrombus in proximity to major end arteries or arteries supplying vital organs.

Competing interests None.

Patient consent Obtained.

Provenance and peer review Not commissioned; externally peer reviewed.

\section{REFERENCES}

1 Learmonth JR, Blackwood W, Richards RL. Localised arterial thrombosis of indeterminate origin. Edinburgh Med J 1944;51:1.

2 Hinkle AWI, Vinson TC. Primary thrombosis of abdominal aorta associated with primary thrombosis of left pulmonary artery; report of a case. Am Surg 1954;20:60.

3 Malyar NM, Janosi RA, Brkovic Z, et al. Large mobile thrombus in non-atherosclerotic thoracic aorta as the source of peripheral arterial embolism. Thromb J 2005:3:19.

Copyright 2013 BMJ Publishing Group. All rights reserved. For permission to reuse any of this content visit http://group.bmj.com/group/rights-licensing/permissions.

BMJ Case Report Fellows may re-use this article for personal use and teaching without any further permission.

Become a Fellow of BMJ Case Reports today and you can:

- Submit as many cases as you like

- Enjoy fast sympathetic peer review and rapid publication of accepted articles

- Access all the published articles

- Re-use any of the published material for personal use and teaching without further permission

For information on Institutional Fellowships contact consortiasales@bmjgroup.com

Visit casereports.bmj.com for more articles like this and to become a Fellow 